\title{
Exogenous acetylcholine alleviates cadmium-induced phytotoxicity by modulating photosynthetic metabolism and antioxidant potential in tobacco (Nicotiana benthamiana)
}

\author{
Y.Y. SU*, Y.Q. CHENG ${ }^{*}$, C. QIN*, N. AHMED ${ }^{* *}$, Y.H. $\mathrm{MU}^{* * *}$, N.S. MUSTAFAD*, M. ASHRAF"\#, \\ and L.X. ZHANG ${ }^{*+}$ \\ College of Life Sciences, Northwest A\&F University, 712100 Yangling, China* \\ Department of Botany, Mohi-Ud-Din Islamic University, 12080 Tarar Khal, Pakistan** \\ Shangluo Branch Company of Shaanxi Tobacco Company, 726000 Shangluo, China*** \\ Pomology Department, National Research Centre, 12622 Cairo, Egypt \\ Department of Botany, University of Agriculture, 38000 Faisalabad, Pakistan
}

\begin{abstract}
Acetylcholine $(\mathrm{ACh})$ plays a potential role in mediating various physiological processes in plants. However, the involvement of acetylcholine in cadmium $(\mathrm{Cd})$ stress tolerance is unknown. Cd stress caused a decline in biomass, pigment, and photosynthetic capacity in Nicotiana benthamiana plants. A significant oxidative stress was evident through enhancing the accumulation of reactive oxygen species and lipid peroxidation. However, pretreatment with acetylcholine ( 50 and $100 \mu \mathrm{M}$ ) effectively decreased oxidative damage, especially by $50 \mu \mathrm{MACh}$, which reduced $\mathrm{H}_{2} \mathrm{O}_{2}$ and $\mathrm{O}_{2}{ }^{--}$contents by 50.4 and $45.3 \%$, respectively, in plants treated with Cd. Our results indicated that the protection of photosynthesis by ACh was attributed to the improved photochemical activity of PSII and inhibited stomatal closure. Additionally, ACh-induced Cd toxicity tolerance was closely associated with improved activities of antioxidant enzymes and ascorbate and glutathione pools. Thus, our results suggest that acetylcholine may act as a positive regulator against Cd toxicity in tobacco.
\end{abstract}

Additional key words: antioxidant system; chlorophyll fluorescence; gas exchange; photoinhibition.

\section{Introduction}

Cadmium (Cd) is considered as a highly toxic element, and it is one of the main environmental limiting factors in physiological and biochemical processes (Clemens 2006). $\mathrm{Cd}$ induces the accumulation of superoxide anion $\left(\mathrm{O}_{2}{ }^{-}\right)$ and hydrogen peroxide $\left(\mathrm{H}_{2} \mathrm{O}_{2}\right)$, which cause oxidative damage, eventually disrupting normal metabolism (Apel and Hirt 2004). Cd also interferes with the photosynthetic efficiency, which is associated with the inhibition of PSII activity (Sharma et al. 2019). Particularly, it inhibits chlorophyll $(\mathrm{Chl})$ biosynthesis, which results from the defects in the electron transport chain in chloroplasts due to the excessive generation of reactive oxygen species (ROS) for cellular redox homeostasis (Asada 2006, Kapoor et al. 2019). Furthermore, overaccumulation of ROS causes membrane damage by inducing lipid peroxidation (malondialdehyde, MDA), which damages to vital bio- molecules (Gill and Tuteja 2010). In order to scavenge ROS, plants have formed diverse defense mechanisms, including the accumulation of osmolytes (i.e., proline, sugar), which maintains cellular homeostasis (Antoniou et al. 2017). Moreover, when exposed to severe prolonged Cd stress, plants have formed an antioxidant defense system that contains both enzymatic antioxidant [ascorbate peroxidase (APX), superoxide dismutase (SOD), catalase $(\mathrm{CAT})$ ] and nonenzymatic antioxidants [glutathione (GSH) and ascorbate (AsA)] to protect cells against detrimental effects of ROS (Asada 1992). It has been indicated that application of some exogenous substances can enhance plants tolerance to $\mathrm{Cd}$ stress by increasing the antioxidant enzyme activities (Li et al. 2019). Besides, both enzymatic and nonenzymatic antioxidants coupled with AsA-GSH cycle have a vital role in the alleviation of various stresses (Ahmad et al. 2018). Thus, maintaining a moderate balance between ROS generation and free radical scavenging

Received 16 February 2020, accepted 22 June 2020.

${ }^{+}$Corresponding author; e-mail: zhanglixin@nwsuaf.edu.cn

Abbreviations: ACh - acetylcholine; APX - ascorbate peroxidase; AsA - ascorbate; CAT - catalase; Chl - chlorophyll; $C_{\mathrm{i}}$ - intercellular $\mathrm{CO}_{2}$ concentration; DHA - dehydroascorbate; $\mathrm{DM}$ - dry mass; $E$ - transpiration rate; $\mathrm{FM}$ - fresh mass; $\mathrm{F}_{\mathrm{v}} / \mathrm{F}_{\mathrm{m}}-$ maximal quantum yield of PSII photochemistry; GSH - glutathione; $g_{s}$ - stomatal conductance; GSSG - glutathione disulfide; MDA - malondialdehyde; NPQ nonphotochemical quenching; $P_{\mathrm{N}}$ - net photosynthetic rate; $\mathrm{q}_{\mathrm{P}}$ - photochemical quenching coefficient; ROS - reactive oxygen species; SOD - superoxide dismutase; TBA - thiobarbituric acid; TCA - trichloroacetic acid; $\mathrm{Y}_{\text {(II) }}$ - actual photochemical efficiency of PSII. Acknowledgments: This work was supported by the National Key Research and Development Program of China (2017YFE0114000), Sci-tec Project of China Tobacco Shaanxi Industrial Co., Ltd. (SXYC-2016-KJ-02) and Sci-tec Project of Shaanxi China Tobacco Industrial Co., Ltd. (JS-FW-2016-001). 
is essential for plant growth and development under Cd stress.

Acetylcholine (ACh) is widely distributed in animals and plants (Horiuchi et al. 2003). In animals, the role of acetylcholine as a neurotransmitter to propagate an electrical stimulus is well-established (Sagane et al. 2005). In plants, ACh regulates growth and development as well as several physiological functions (Tretyn and Kendrick 1991, Kawashima et al. 2007). Studies have shown that $\mathrm{ACh}$, as a signal molecule, is closely related to regulating elongation of lateral roots, and pro-moting dry matter accumulation (Sugiyama and Tezuka 2011, Braga et al. 2017). Momonoki and Tokuhiro (1992) reported that the $\mathrm{ACh}$ is sensitive to gravity changes, $\mathrm{Ca}^{2+}$ concentration, and distribution of hormones under environmental stresses. It has been demonstrated that exogenously applied ACh can effectively ameliorate the adverse effects of salt stress in Nicotiana benthamiana (Qin et al. 2019). However, there is no relevant information about whether $\mathrm{ACh}$ can ameliorate $\mathrm{Cd}$-induced damage in plants.

Nicotiana benthamiana, as a crucial model plant, has the characteristics of dwarf phenotype, short growth cycle, and can be successfully infected by the great majority of plant viruses, which has been widely used in transgenic experiments. To date, no investigation has been reported regarding the potential role of acetylcholine in heavy metal stress of tobacco plants. The hypothesis was that Cd-induced photoinhibition and oxidative stress were observed in tobacco plants and then such a process could be effectively alleviated by acetylcholine addition. In this study, the effects of acetylcholine on physiological processes, including growth attributes, photosynthetic performance, stomatal morphology, membrane lipid peroxidation, antioxidant and nonenzymatic antioxidants during $\mathrm{Cd}$ stress were studied. The potential mechanisms of the protections of acetylcholine were also explored and discussed. The results can provide further revealing of the potential roles of acetylcholine in regulating heavy metal stress.

\section{Materials and methods}

Plant treatments: Seeds of tobacco (Nicotiana benthamiana) were provided by Laboratory of Plant Physiology, Nanjing Agricultural University. Seeds were surface sterilized with $5 \% \mathrm{NaClO}$ for $5 \mathrm{~min}$ and washed with distilled water two times, then soaked in sterile water for $24 \mathrm{~h}$ at $25^{\circ} \mathrm{C}$ in the darkness. The uniform seedlings were transplanted in the plastic pots $(245 \times 170 \times 75 \mathrm{~mm})$ and grown in a growth chamber. The day/night air temperature was maintained at $25 / 18^{\circ} \mathrm{C}$ with 16 -h day length, relative humidity of $60-70 \%$, and light intensity of 800 $\mu$ mol(photon) $\mathrm{m}^{-2} \mathrm{~s}^{-1}$. To ensure the tobacco seedlings grow normally, plants were cultured with 1/2 Hoagland nutrient solution, which was changed every $2 \mathrm{~d}$ to keep a constant solution concentration. When six leaves were expanded, the seedlings were treated with different concentrations of ACh [Sigma-Aldrich $(\geq 99 \%$, St. Louis, USA)] solution $(0,5,10,50,100$ or $150 \mu \mathrm{M})$. After $3 \mathrm{~d}$ of pretreatment with $\mathrm{ACh}$, the seedlings were treated with
$100 \mu \mathrm{M} \mathrm{CdCl}_{2}$ (analytical grade, this concentration was selected by a previous trial, unpublished data). Briefly, the seedlings were separated into seven groups based on different treatments. Treatments were performed as reffered in the text table. The experiment was performed in triplicate and each replicate consisted of 12 plants, the plants were sampled after $15 \mathrm{~d}$ of $\mathrm{Cd}$ exposure then stored at $-80^{\circ} \mathrm{C}$ until further analysis.

The growth parameters were measured after $15 \mathrm{~d}$ of $\mathrm{Cd}$ stress. Plant height and root length were obtained adopting a manual scale. The fresh mass of tobacco seedlings was taken after washing with distilled water. To determine the dry mass, the leaf tissues were dried to a constant mass at $60^{\circ} \mathrm{C}$ for $72 \mathrm{~h}$.

SPAD index and leaf pigments: The relative chlorophyll (Chl) content of seedlings (fully expanded leaves from top) were measured with a Chl meter (SPAD-502, Minolta, Japan). The Chl content was also determined following the method of Wintermans and De Mots (1965). Leaves $(0.1 \mathrm{~g})$ were extracted using $10 \mathrm{~mL}$ of $95 \%$ ethanol after shaking at room temperature for $24 \mathrm{~h}$ in darkness. After centrifugation at $5,000 \times g$ for $15 \mathrm{~min}$, an absorbance of the supernatant was determined at 649 and $665 \mathrm{~nm}$ using a spectrophotometer (UV-2800, Shimadzu, Kyoto, Japan). The concentration was estimated according to the formula: Total $\mathrm{Chl}=18.08 \times \mathrm{A}_{649}+6.63 \times \mathrm{A}_{665}$.

Gas-exchange parameters: The second fully expanded leaves from the top were selected to measure net photosynthetic rate $\left(P_{\mathrm{N}}\right)$, stomatal conductance $\left(g_{\mathrm{s}}\right)$, intercellular $\mathrm{CO}_{2}$ concentration $\left(C_{\mathrm{i}}\right)$, and transpiration rate $(E)$ using a photosynthesis system ( $L i-6400 X T$, Lincoln, Nebraska, USA) during the morning (8:30-10:30 h). The measuring system was controlled to maintain leaf temperature at $25 \pm 2{ }^{\circ} \mathrm{C}, \mathrm{CO}_{2}$ concentration was set at $400 \mu \mathrm{mol}\left(\mathrm{CO}_{2}\right)$ $\mathrm{mol}^{-1}$, and PAR was $1,000 \mu \mathrm{mol}\left(\right.$ photon) $\mathrm{m}^{-2} \mathrm{~s}^{-1}$.

PSII activity: The second fully expanded leaves from the top were determined with Open FluorCam (FC800-C/1010, Germany) after a 25-min dark adaptation. The maximum photochemical efficiency of PSII $\left(\mathrm{F}_{\mathrm{v}} / \mathrm{F}_{\mathrm{m}}\right)$ and actual photochemical efficiency of PSII [Y $\mathrm{Y}_{(\mathrm{II})}$ ] was calculated according to the method of Genty et al. (1989). The nonphotochemical quenching (NPQ) and photochemical quenching coefficient $\left(\mathrm{q}_{\mathrm{P}}\right)$ were assayed using the method described by Tambussi et al. (2002).

Stomata: The fourth fully expanded leaves from the plant top were cut into $5 \times 5 \mathrm{~mm}$ segments and fixed with FAA (formalin-acetic acid-alcohol) solution overnight, then washed two times with distilled water for $10 \mathrm{~min}$ at each step. Finally, the samples were placed on glass slides before observation. The samples were observed using a microscope (Leica, Model DMi8, Germany). The morphometric parameters of stomatal aperture and density were estimated following procedure of Snider et al. (2009).

In vivo visualization of ROS: The $\mathrm{O}_{2}{ }^{--}$staining was assayed as the procedure described by Kim et al. (2012). 


\begin{tabular}{ll}
\hline Treatment & \\
\hline Control & $1 / 2$ Hoagland nutrient solution \\
$\mathrm{Cd}$ & $1 / 2$ Hoagland nutrient solution $+100 \mu \mathrm{M} \mathrm{Cd}$ \\
$5 \mathrm{ACh}+\mathrm{Cd}$ & $5 \mu \mathrm{M} \mathrm{ACh}+1 / 2$ Hoagland nutrient solution $+100 \mu \mathrm{M} \mathrm{Cd}$ \\
$10 \mathrm{ACh}+\mathrm{Cd}$ & $10 \mu \mathrm{M} \mathrm{ACh}+1 / 2$ Hoagland nutrient solution $+100 \mu \mathrm{M} \mathrm{Cd}$ \\
$50 \mathrm{ACh}+\mathrm{Cd}$ & $50 \mu \mathrm{M} \mathrm{ACh}+1 / 2$ Hoagland nutrient solution $+100 \mu \mathrm{M} \mathrm{Cd}$ \\
$100 \mathrm{ACh}+\mathrm{Cd}$ & $100 \mu \mathrm{M} \mathrm{ACh}+1 / 2$ Hoagland nutrient solution $+100 \mu \mathrm{M} \mathrm{Cd}$ \\
$150 \mathrm{ACh}+\mathrm{Cd}$ & $150 \mu \mathrm{M} \mathrm{ACh}+1 / 2$ Hoagland nutrient solution $+100 \mu \mathrm{M} \mathrm{Cd}$ \\
\hline
\end{tabular}

After removal from plants, leaves were incubated in $0.5 \mathrm{mg} \mathrm{mL}^{-1}$ of nitroblue tetrazolium (NBT, $\mathrm{pH} 7.8$ ) solution under darkness. $\mathrm{H}_{2} \mathrm{O}_{2}$ production was assayed by 3,3-diaminobenzidine (DAB) staining, adopting the procedure described by Christensen et al. (1997). Leaves were incubated in $1 \mathrm{mg} \mathrm{mL}^{-1}$ of DAB solution $(\mathrm{pH} 7.8)$ and in the absence of light for $5 \mathrm{~h}$ at $25^{\circ} \mathrm{C}$. Then the leaves were washed in $95 \%(\mathrm{v} / \mathrm{v})$ ethanol every $20 \mathrm{~min}$ at $80^{\circ} \mathrm{C}$ until complete removal of green background.

$\mathrm{O}_{2}{ }^{--}$and $\mathrm{H}_{2} \mathrm{O}_{2}$ analysis: $\mathrm{O}_{2}{ }^{--}$was measured as described by Schopfer et al. (2001). Fresh leaves were homogenized with $5 \mathrm{~mL}$ of $50 \mathrm{mM}$ phosphate buffer ( $\mathrm{pH} 7.8$ ). The homogenized material was centrifuged at $12,000 \times g$ for $20 \mathrm{~min}$. Then, the supernatant was used for the determination of $\mathrm{O}_{2}{ }^{-}$production, which was calculated using a standard curve based on sodium nitrite and expressed in mol $\mathrm{g}^{-1}(\mathrm{FM}) \mathrm{min}^{-1}$.

To estimate $\mathrm{H}_{2} \mathrm{O}_{2}$ concentration, fresh leaves were homogenized with $5 \mathrm{~mL}$ of ice-cold $0.1 \%(\mathrm{w} / \mathrm{v})$ trichloroacetic acid, followed by centrifugation at $10,000 \times g$ for $20 \mathrm{~min}$ at $4^{\circ} \mathrm{C}$. Supernatants were collected and combined with $0.5 \mathrm{~mL} 0.1 \mathrm{M}$ potassium phosphate buffer $(\mathrm{pH} 7.0)$ and $1 \mathrm{~mL}$ of KI solution, and absorbance was recorded at $390 \mathrm{~nm}$ ( $U V-2800$, Shimadzu, Kyoto, Japan). The concentration of $\mathrm{H}_{2} \mathrm{O}_{2}$ was based on $\mathrm{H}_{2} \mathrm{O}_{2}$ standard curve and expressed as $\mathrm{mmol} \mathrm{g}^{-1}$ (FM) (Patterson et al. 1984).

Determination of leaf malondialdehyde (MDA): The MDA assay was a modification of the procedure of Tonutti et al. (1997). Fresh leaf tissues (0.2 g) were homogenized in $5 \mathrm{~mL}$ of $0.1 \%(\mathrm{w} / \mathrm{v})$ trichloroacetic acid (TCA) and centrifuged at $4,000 \times g$ for $15 \mathrm{~min}$ at $4^{\circ} \mathrm{C}$. Supernatant $(1 \mathrm{~mL})$ was mixed with $4 \mathrm{~mL}$ of $20 \%$ TCA, containing $0.65 \%(\mathrm{w} / \mathrm{v})$ thiobarbituric acid (TBA). The mixture was heated in a water bath for $10 \mathrm{~min}$, then immediately centrifuged for $15 \mathrm{~min}$ at 4,500 $\times \mathrm{g}$ and its absorbance was recorded at 450, 532, and $660 \mathrm{~nm}(U V-2800$, Shimadzu, Kyoto, Japan).

Proline accumulation: Briefly, leaf samples $(0.2 \mathrm{~g})$ were homogenized in $7.5 \mathrm{~mL}$ of $3 \%$ sulfosalicylic acid. The mixture solution containing $2 \mathrm{~mL}$ of filtrate, $2 \mathrm{~mL}$ of $2.5 \%$ ninhydrin reagent, and $2 \mathrm{~mL}$ of glacial acetic acid was kept in a boiling water for $1 \mathrm{~h}$ and then placed on ice for $30 \mathrm{~min}$. Then, the reaction mixture was extracted using $4 \mathrm{~mL}$ of toluene. The absorbance of the extract was read at $520 \mathrm{~nm}(U V-2800$, Shimadzu, Kyoto, Japan) (Bates et al. 1973).
Assay of antioxidant enzymes: For enzyme analyses, fresh leaf tissues $(0.2 \mathrm{~g})$ were homogenized in $3 \mathrm{~mL}$ of ice-cold phosphate buffer $(50 \mathrm{mM}, \mathrm{pH} 7.0)$ consisting of $0.2 \mathrm{mM}$ EDTA and $2 \%(\mathrm{w} / \mathrm{v})$ polyvinylpyrrolidone. The homogenate was centrifuged at $12,000 \times g$ for $20 \mathrm{~min}$ at $4^{\circ} \mathrm{C}$, and the supernatant was used for the assay of antioxidant enzymes. Superoxide dismutase (SOD, EC 1.15.1.1) activity was estimated by measuring the inhibition of photochemical reduction of NBT following the procedure of Giannopolitis and Ries (1977). The reaction mixture $(3 \mathrm{~mL})$ comprised of $50 \mathrm{mM} \mathrm{Na}_{2} \mathrm{HPO}_{4}$ $\mathrm{NaH}_{2} \mathrm{PO}_{4}$ buffer, $3 \mathrm{mM}$ EDTA, $1 \mathrm{mM}$ NBT, $14 \mathrm{mM}$ methionine, $60 \mathrm{mM}$ riboflavin, and $100 \mu \mathrm{L}$ of enzyme extract. One unit of SOD was defined as the amount of enzyme, which inhibited the NBT reduction by $50 \%$ at $560 \mathrm{~nm}$.

For ascorbate peroxidase (APX, EC 1.11.1.11) activity assay, $3 \mathrm{~mL}$ of reaction mixture contained $50 \mathrm{mM}$ sodium phosphate buffer ( $\mathrm{pH} 7.0), 9 \mathrm{mM}$ ascorbic acid, $12.5 \mathrm{mM}$ $\mathrm{H}_{2} \mathrm{O}_{2}$, and $100 \mu \mathrm{L}$ of enzyme extract (Nakano and Asada 1981). The activity was calculated by recording the decrease in absorbance at $290 \mathrm{~nm}$ per min $(U V-2800$, Shimadzu, Kyoto, Japan).

Catalase (CAT, EC 1.11.1.6) activity was assayed using the method of Cakmak and Marschner (1992). For the assay of CAT, the reaction mixture $(3 \mathrm{~mL})$ contained $12.5 \mathrm{mM} \mathrm{H}_{2} \mathrm{O}_{2}, 50 \mathrm{mM}$ sodium phosphate buffer ( $\mathrm{pH} 7.0$ ), and $200 \mu \mathrm{L}$ of enzyme extract. The decomposition of $\mathrm{H}_{2} \mathrm{O}_{2}$ was determined by recording the absorbance at $240 \mathrm{~nm}$.

Ascorbate and glutathione contents: The method of Masato (1980) was adopted for the measurement of ascorbate (AsA) and dehydroascorbate (DHA) contents. Fresh leaf tissues $(0.1 \mathrm{~g})$ were homogenized in $5 \%$ trichloroacetic acid and centrifuged at $4{ }^{\circ} \mathrm{C}$ for $15 \mathrm{~min}$ at $15,000 \times g$. For total AsA, the reaction mixture comprised of $0.2 \mathrm{~mL}$ of the supernatant, $0.5 \mathrm{~mL}$ of $50 \mathrm{mM}$ phosphate buffer ( $\mathrm{pH}$ 7.4) containing $5 \mathrm{mM}$ EDTA and $0.1 \mathrm{~mL}$ of $10 \mathrm{mM}$ DTT. After incubation for $10 \mathrm{~min}$ at $25^{\circ} \mathrm{C}$, the reaction mixture was added to $0.15 \mathrm{~mL}$ of $0.5 \%$ N-ethylmaleimide to remove excess DTT. For measurement of AsA, $200 \mu \mathrm{L}$ of deionized $\mathrm{H}_{2} \mathrm{O}$ was substituted for DTT and N-ethylmaleimide. Next, the reaction mixtures were added to $400 \mu \mathrm{L}$ of $10 \%$ TCA, $400 \mu \mathrm{L}$ of $44 \%$ phosphoric acid, $400 \mu \mathrm{L} 70 \% \alpha$-dipyridyl in ethanol, and $200 \mu \mathrm{L}$ of $0.3 \%(\mathrm{w} / \mathrm{v}) \mathrm{FeCl}_{3}$. The mixture was incubated at $40^{\circ} \mathrm{C}$ for $40 \mathrm{~min}$ in a water bath and the absorbance was recorded at $525 \mathrm{~nm}$ (UV-2800, Shimadzu, Kyoto, Japan). 
The DHA concentration was detected by subtracting the AsA concentration from the total AsA concentration.

Glutathione (GSH) and glutathione disulfide (GSSG) were measured by the method of Kampfenkel et al. (1995) and Smith (1985). Fresh leaf tissues were ground in $2 \mathrm{~mL}$ of 5\% sulfosalicylic acid containing $2 \mathrm{mM}$ EDTA and centrifuged at $4^{\circ} \mathrm{C}$ for $10 \mathrm{~min}$ at $12,000 \times g$. For the total glutathione assay, $100 \mu \mathrm{L}$ of the supernatant was added to $50 \mathrm{mM}$ phosphate buffer $(\mathrm{pH} 7.5)$ containing $5 \mathrm{mM}$ EDTA, $20 \mu \mathrm{L}$ of $10 \mathrm{mM}$ NADPH, and $80 \mu \mathrm{L}$ of $12.5 \mathrm{mM}$ DTNB. The reaction was started by adding $20 \mu \mathrm{L}$ of GR $\left(50 \mathrm{U} \mathrm{mL}^{-1}\right)$ and was monitored by measuring the changes in absorbance at $412 \mathrm{~nm}(U V-2800$, Shimadzu, Kyoto, Japan).

GSH was masked by adding $20 \mu \mathrm{L}$ of 2-vinylpyridine to the neutralized supernatant for the GSSG assay. The GSH concentration was obtained by subtracting the GSSG concentration from the total concentration.

Cd concentration: The root and leaf tissues were dried at $60^{\circ} \mathrm{C}$ until reaching the constant mass. Then the dried tissues $(0.1 \mathrm{~g})$ were ground to powder and digested with concentrated $\mathrm{HClO}_{4} / \mathrm{HNO}_{3}(1: 4, \mathrm{v} / \mathrm{v})$. Thereafter, the concentration of $\mathrm{Cd}$ was measured following the procedures of Wu et al. (2005) using an atomic absorption spectrophotometer (Z-2000, Hitachi, Japan).

Statistical analysis: The values are presented as mean \pm standard deviation (SD) of independent replicates. Statistical significance of the treatments was by analysis of variance test (ANOVA) followed by mean separation by Duncan's multiple range test at $P<0.05$.

\section{Results}

Plant growth: As shown in Fig. $1 A$, the leaf rolls and chlorosis were obviously found in $\mathrm{Cd}$ alone treatment. It was apparent that application of ACh $(5-150 \mu \mathrm{M})$ improved the degree of leaf chlorosis and growth of tobacco seedlings, compared to control treatment (Fig. 1A). Meanwhile, Cd stress inhibited biomass accumulation in tobacco seedlings. However, application of ACh reduced $\mathrm{Cd}$-induced inhibition in plant biomass. In the $\mathrm{Cd}$ alone treatment, values for FM and DM were reduced by 39.8 and $43.7 \%$, respectively, in comparison with the control plants. Moreover, Cd stress treatment reduced the plant height of tobacco seedlings, while pretreated by ACh effectively alleviated this phenomenon (Fig. $1 B-D$ ). Furthermore, ACh with $5,10,100$ or $150 \mu \mathrm{M}$ concentration showed no obvious promotion in biomass accumulation and plant height under Cd toxicity, relative to the results of $50 \mu \mathrm{M}$ acetylcholine.

Photosynthesis attributes: Our data demonstrated that $\mathrm{Cd}$ stress alone decreased total Chl content and SPAD by 38.5 and $47.9 \%$, respectively, relative to the control treatment plants (Fig. 2A,B). It is noteworthy that application of ACh resulted in higher SPAD index and total Chl content than that of $\mathrm{Cd}$ alone treatment. $\mathrm{Cd}$ stress drastically decreased $P_{\mathrm{N}}, g_{\mathrm{s}}, C_{\mathrm{i}}$, and $E$ by $48.4,70.2,16.3$, and $53.1 \%$, respectively, in comparison to control treatment. However, pretreatment with various concentrations $(5,10$, 100 , and $150 \mu \mathrm{M}$ ) of ACh obviously alleviated Cd stress in leaves. Especially, application of $50 \mu \mathrm{M}$ ACh was the most optimal concentration in alleviating photosynthetic inhibition (Fig. 2C-F).

PSII activity: To determine whether ACh was involved in $\mathrm{Cd}$ tolerance, we assayed $\mathrm{Chl}$ fluorescence attributes in leaves. Notably, Cd-induced reductions in $\mathrm{F}_{\mathrm{v}} / \mathrm{F}_{\mathrm{m}}, \mathrm{Y}_{(\mathrm{II})}$, and $\mathrm{q}_{\mathrm{P}}$ were markedly alleviated by the treatments with moderate concentration of $\mathrm{ACh}$. Cd alone stress decreased $\mathrm{F}_{\mathrm{v}} / \mathrm{F}_{\mathrm{m}}, \mathrm{Y}_{(\mathrm{II})}, \mathrm{q}_{\mathrm{P}}$ by $35.2,17.1,25.3 \%$, respectively, compared to the control treatment. Among the tested concentrations of $\mathrm{ACh}$, the optimal concentration of $50 \mu \mathrm{M}$ exhibited remarkable ameliorative effect as evident by 18.3, 14.9, and $11.8 \%$ increase in $\mathrm{F}_{\mathrm{v}} / \mathrm{F}_{\mathrm{m}}, \mathrm{Y}_{(\mathrm{II})}$, and $\mathrm{q}_{\mathrm{P}}$, respectively, compared with the $\mathrm{Cd}$ alone treatment. When the
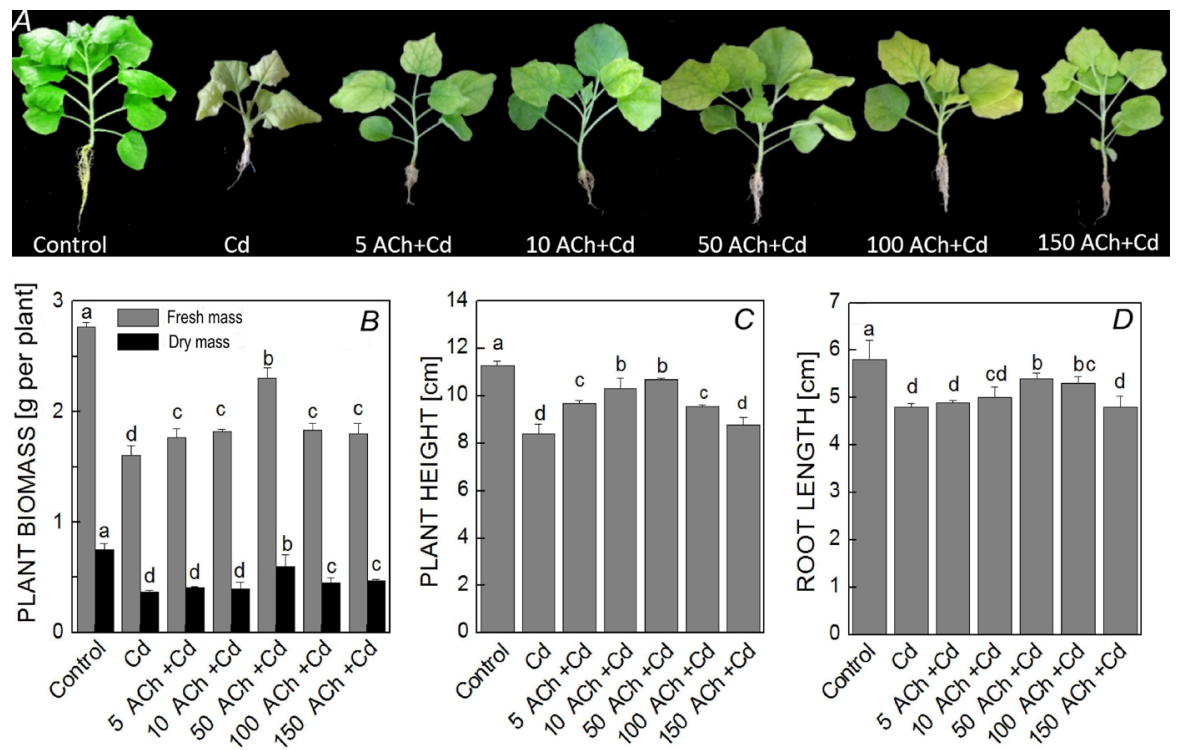

Fig. 1. Effects of exogenous acetylcholine on growth conditions after $15 \mathrm{~d}$ of $\mathrm{Cd}$ stress. (A) Phenotypic changes of tobacco seedlings, $(B)$ fresh mass (FM) and dry mass (DM), $(C)$ plant height, $(D)$ root length. Data are means of three replicates $\pm \mathrm{SD}$. Bars with different letters indicate significant difference between treatments at $p \leq 0.05$ by Duncan's multiple range test. Control $-1 / 2$ Hoagland nutrient solution. $\mathrm{Cd}-1 / 2$ Hoagland nutrient solution $+100 \mu \mathrm{M} \mathrm{Cd}$. $5,10,50,100$ or $150 \mathrm{ACh}+\mathrm{Cd}-$ $1 / 2$ Hoagland nutrient solution + $5,10,50,100$ or $150 \mu \mathrm{M} \mathrm{ACh}+$ $100 \mu \mathrm{M} \mathrm{Cd}$. 
Cd-stressed plants received different concentrations $(5-150 \mu \mathrm{M})$ of ACh, especially $50 \mu \mathrm{M}$, a significant ameliorative decrease of NPQ (36.1\%) was found, compared with $\mathrm{Cd}$ alone treatment (Fig. 3).

Stomata structure: To verify whether ACh-induced Cd tolerance is associated with stomatal behaviour, we analyzed stomatal density and aperture in leaves. As shown in Fig. 4, Cd led to decreases in the stomatal density and aperture, while pretreatment with ACh $(10-50 \mu \mathrm{M})$ led to a significant increase in the stomatal aperture. Especially, pretreatment with $50 \mu \mathrm{M}$ ACh markedly increased the
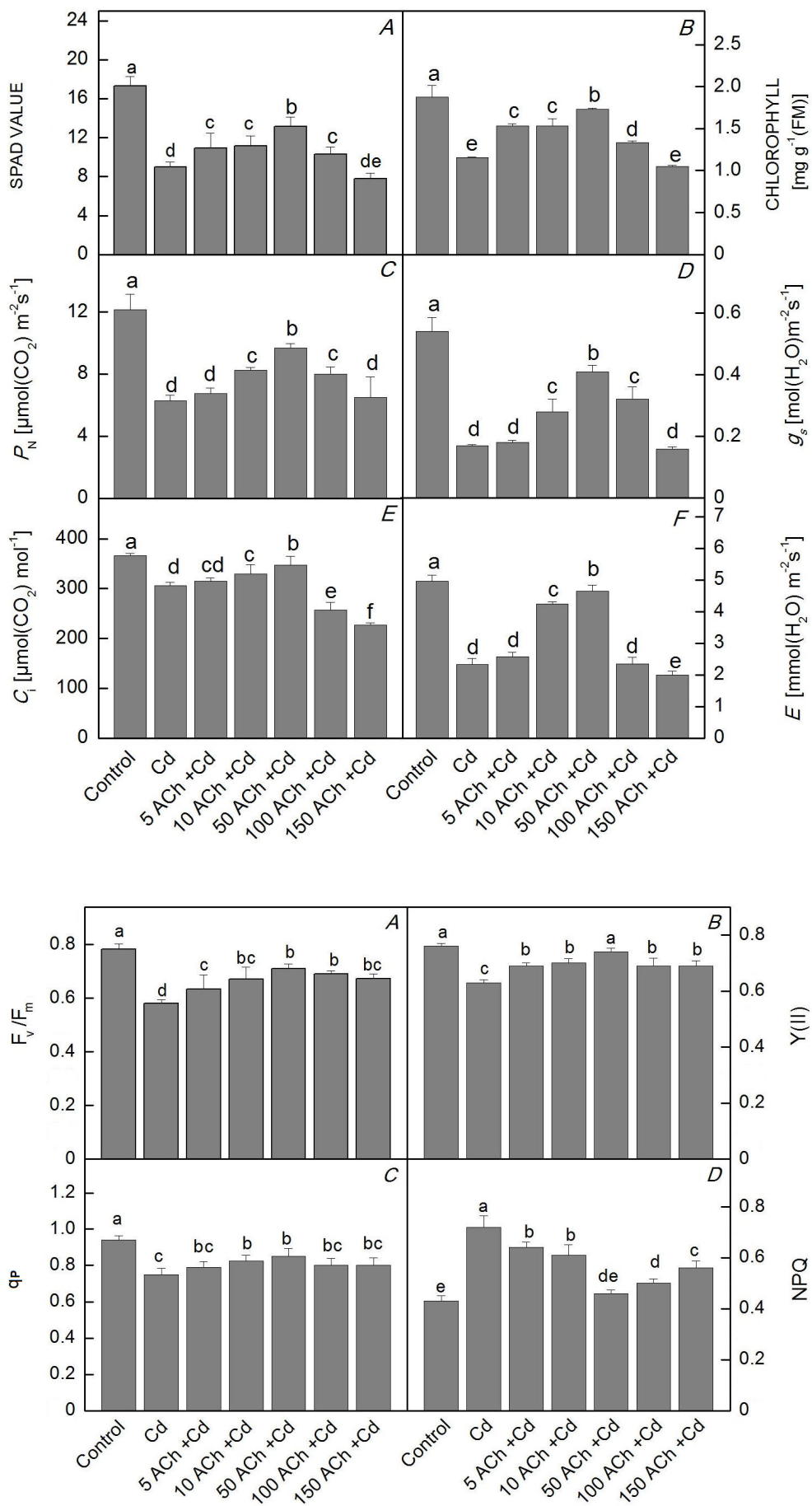

stomatal density by $39.0 \%$, compared to the treatment with $\mathrm{Cd}$ stress alone. Additionally, no significant differences were found in the stomatal aperture and stomata density between the 100 and $150 \mu \mathrm{M}$ ACh-treated plants (Fig. 4).

ROS, MDA, and proline accumulation: Cd-exposure caused the generation of ROS, as evidenced by NBT and DAB staining in the leaves. $\mathrm{O}_{2}^{-}$is indicated by dark blue spots (Fig. $5 \mathrm{~A}$ ) and $\mathrm{H}_{2} \mathrm{O}_{2}$ is indicated by brown spots (Fig. $5 B$ ). Cd alone treatment was stained extensively in tobacco leaf, indicating that a severe cellular redox imbalance appeared. However, supplementation of ACh to

Fig. 2. Effects of exogenous acetylcholine on photosynthetic pigments and gas-exchange parameters in tobacco seedlings after $15 \mathrm{~d}$ of Cd stress. $(A)$ SPAD index, $(B)$ chlorophyll content, $(C)$ net photosynthetic rate $\left(P_{\mathrm{N}}\right),(D)$ stomatal conductance $\left(g_{\mathrm{s}}\right),(E)$ intercellular $\mathrm{CO}_{2}$ concentration $\left(C_{\mathrm{i}}\right)$, $(F)$ transpiration rate $(E)$. Data are means of three replicates $\pm \mathrm{SD}$. Bars with different letters indicate significant difference between treatments at $p \leq 0.05$ by Duncan's multiple range test. Control 1/2 Hoagland nutrient solution. Cd $-1 / 2$ Hoagland nutrient solution $+100 \mu \mathrm{M}$ Cd. $5,10,50,100$ or $150 \mathrm{ACh}+\mathrm{Cd}-1 / 2$ Hoagland nutrient solution +5 , $10,50,100$ or $150 \mu \mathrm{M} \mathrm{ACh}+100 \mu \mathrm{M} \mathrm{Cd}$.

Fig. 3. Effects of exogenous acetylcholine on PSII in tobacco seedlings after $15 \mathrm{~d}$ of Cd stress. (A) maximum quantum yield of PSII $\left(\mathrm{F}_{\mathrm{v}} / \mathrm{F}_{\mathrm{m}}\right)$, $(B)$ actual photochemical efficiency of PSII [Y $\left.\mathrm{Y}_{(\mathrm{II})}\right]$, (C) photochemical quenching coefficient ( $\mathrm{q}_{\mathrm{p}}$ ), $(D)$ nonphotochemical quenching (NPQ). Data are means of three replicates \pm SD. Bars with different letters indicate significant difference between treatments at $p \leq 0.05$ by Duncan's multiple range test. Control $-1 / 2$ Hoagland nutrient solution. $\mathrm{Cd}$ $-1 / 2$ Hoagland nutrient solution $+100 \mu \mathrm{M} \mathrm{Cd}$. $5,10,50,100$ or $150 \mathrm{ACh}+\mathrm{Cd}-1 / 2$ Hoagland nutrient solution $+5,10,50,100$ or $150 \mu \mathrm{M} \mathrm{ACh}+$ $100 \mu \mathrm{M} \mathrm{Cd}$. 
Cd-stressed plants showed slight staining. In comparison with control plants, $\mathrm{O}_{2}{ }^{-}$and $\mathrm{H}_{2} \mathrm{O}_{2}$ contents markedly increased after $\mathrm{Cd}$ alone treatment, whereas the exogenous application of $\mathrm{ACh}$ significantly reduced $\mathrm{Cd}$-induced accumulation of $\mathrm{O}_{2}{ }^{--}$and $\mathrm{H}_{2} \mathrm{O}_{2}$ (Fig. 5C,D). $50 \mu \mathrm{M}$ ACh concentration was effective for alleviating $\mathrm{Cd}$-induced accumulation of $\mathrm{O}_{2}{ }^{--}$and $\mathrm{H}_{2} \mathrm{O}_{2}$. The application of 5 or $150 \mu \mathrm{M}$ ACh showed to be less effective in decreasing ROS generation under Cd stress as compared to $50 \mu \mathrm{M}$ concentration. Cd stress also caused severe oxidative damage to cell membranes. When tobacco seedlings were exposed to $\mathrm{Cd}$ alone stress, the contents of MDA dramatically increased 2.04-fold, as compared to control plants. However, pretreatment with ACh $(50 \mu \mathrm{M})$ markedly reduced MDA content which was about $31.2 \%$ lower than that of the Cd alone treatment. Further, Cd stress also led to a remarkable accumulation of proline in leaves. Whereas, the treatments with different concentrations of ACh caused an increase in the proline in comparison with $\mathrm{Cd}$ stress alone. Application dose of $50 \mu \mathrm{M}$ Ach along with $\mathrm{Cd}$ stress significantly increased the proline content by $44.5 \%$, compared with Cd alone stress seedlings (Fig. 5E,F).

Activities of antioxidant enzymes: We also assessed the activities of vital antioxidant enzymes, such as SOD, APX, CAT, which significantly decreased by $\mathrm{Cd}$ alone treatment. Pretreatment with ACh led to much higher SOD activity than that measured in the control. Similar changes were observed in the APX and CAT activities. For instance, when treated with $50 \mu \mathrm{M}$ ACh, the activity of antioxidant enzymes SOD, APX, and CAT increased 1.55, 0.78, and 2.13 times, respectively, in comparison with the control plants (Fig. 6).
Redox homeostasis: Compared with the control group, GSH and AsA values decreased, while glutathione disulfide (GSSG) and dehydroascorbate (DHA) contents were enhanced by $\mathrm{Cd}$ stress alone. However, pretreatment with ACh significantly increased GSH and AsA contents, whereas GSSG and DHA contents declined under Cd alone. When pretreated with lower concentration of ACh $(5-50 \mu \mathrm{M})$, the content of GSH and AsA markedly increased. However, pretreatment with all concentrations of ACh $(5-150 \mu \mathrm{M})$ caused no significant changes in GSSG and DHA (Fig. 7).

Cd accumulation: We investigated also the effect of ACh on $\mathrm{Cd}$ content in roots and leaves of tobacco seedlings. Table 1 showed that the maximum accumulation of $\mathrm{Cd}$ were observed in the leaves and roots, after exposure to $\mathrm{Cd}$ alone stress. Supplementation of $50 \mu \mathrm{M}$ ACh obviously decreased the $\mathrm{Cd}$ uptake by $30.5 \%$ in root tissues. Application of various concentrations of ACh significantly decreased the $\mathrm{Cd}$ content in leaves, compared to $\mathrm{Cd}$ alone stress. However, there were no significant differences observed between all concentrations $(10-150 \mu \mathrm{M})$ of ACh.

\section{Discussion}

Cadmium $(\mathrm{Cd})$ is a widespread environmental pollutant because of its long half-life in soil, which alters the biochemical and physiological processes of plants. $\mathrm{Cd}$ toxicity induces lipid peroxidation and ROS accumulation, and then interferes with photosynthesis and growth (Cho and Seo 2005, Rahman et al. 2017). Therefore, it is necessary to reduce its phytotoxicity. Here, the potential feasibility of ACh application has been demonstrated in
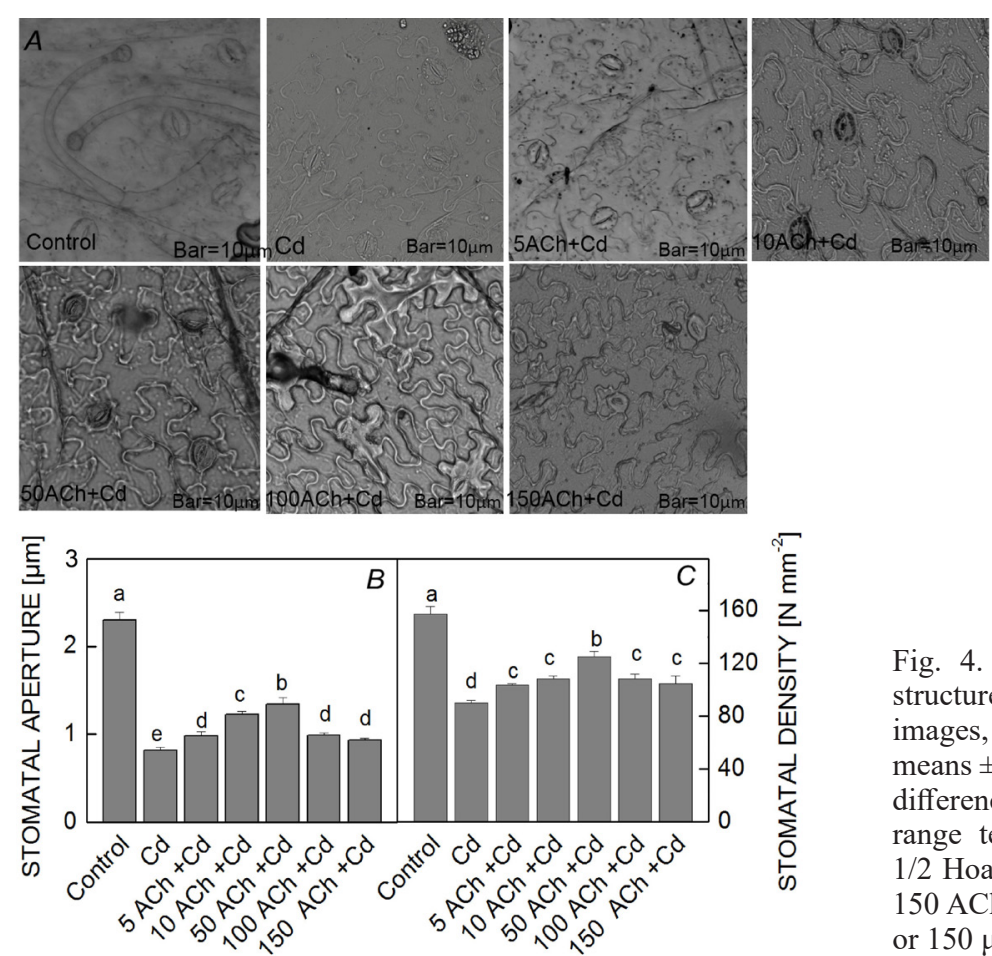

Fig. 4. Effects of exogenous acetylcholine on the stomatal structure of tobacco under Cd stress. $(A)$ stomatal morphology images, $(B)$ stomatal aperture, $(C)$ stomatal density. Data are the means $\pm \mathrm{SD}, n=5$. Bars with different letters indicate significant difference between treatments at $p \leq 0.05$ by Duncan's multiple range test. Control $-1 / 2$ Hoagland nutrient solution. $\mathrm{Cd}-$ $1 / 2$ Hoagland nutrient solution $+100 \mu \mathrm{M} \mathrm{Cd} .5,10,50,100$ or $150 \mathrm{ACh}+\mathrm{Cd}-1 / 2$ Hoagland nutrient solution $+5,10,50,100$ or $150 \mu \mathrm{M} \mathrm{ACh}+100 \mu \mathrm{M} \mathrm{Cd}$. 

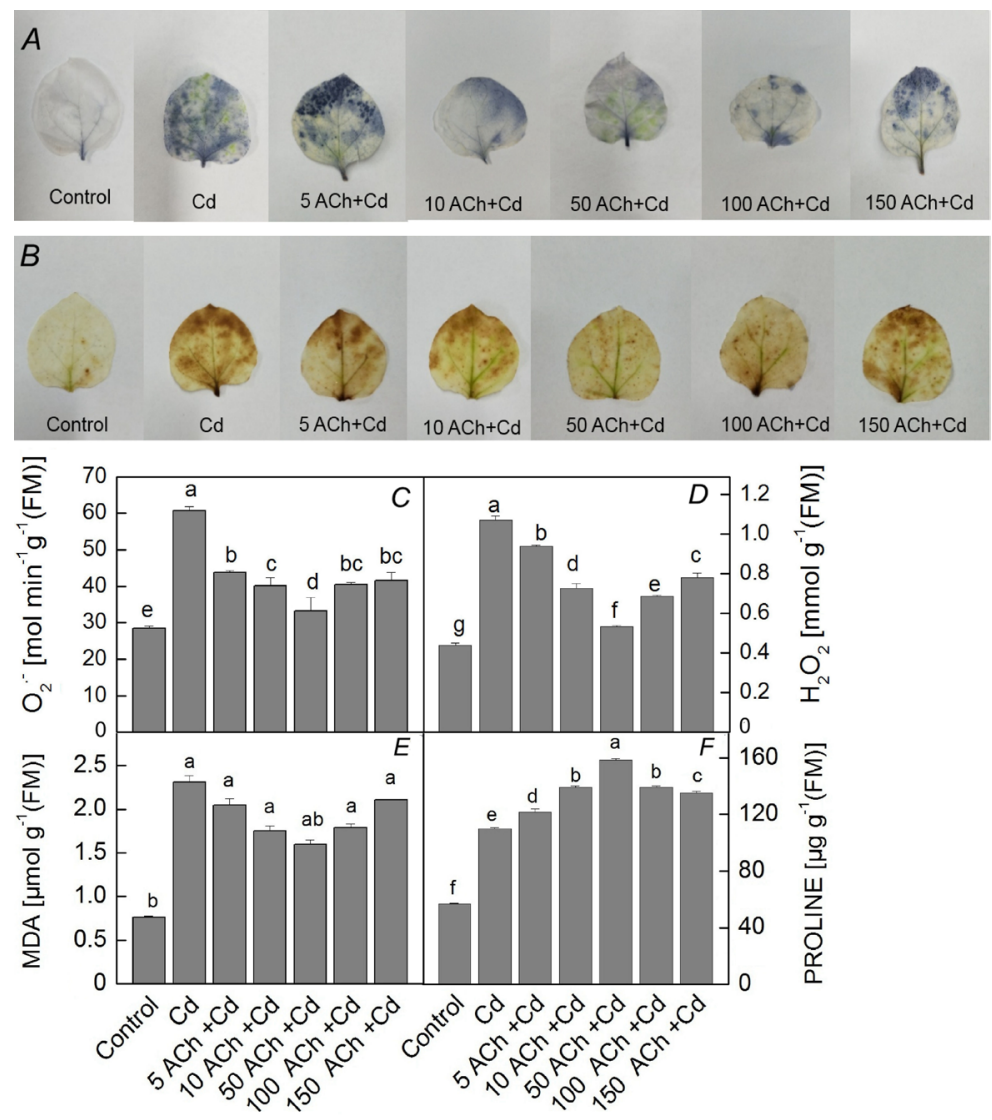

Fig. 5. Effects of exogenous acetylcholine on the production of ROS in tobacco seedlings after $15 \mathrm{~d}$ of $\mathrm{Cd}$ stress. $(A)$ histochemical staining of $\mathrm{O}_{2}^{-{ }^{-}}$, (B) histochemical staining of $\mathrm{H}_{2} \mathrm{O}_{2},(C) \mathrm{O}_{2}{ }^{-}$content, $(D) \mathrm{H}_{2} \mathrm{O}_{2}$ content, $(E)$ malondialdehyde (MDA) content, $(F)$ proline content. Data are means of three replicates \pm SD. Bars with different letters indicate significant difference between treatments at $p \leq 0.05$ by Duncan's multiple range test. Control $-1 / 2$ Hoagland nutrient solution. $\mathrm{Cd}-1 / 2$ Hoagland nutrient solution $+100 \mu \mathrm{M} \mathrm{Cd}$. $5,10,50,100$ or $150 \mathrm{ACh}+\mathrm{Cd}-1 / 2$ Hoagland nutrient solution $+5,10,50$, 100 or $150 \mu \mathrm{M} \mathrm{ACh}+100 \mu \mathrm{M} \mathrm{Cd}$.

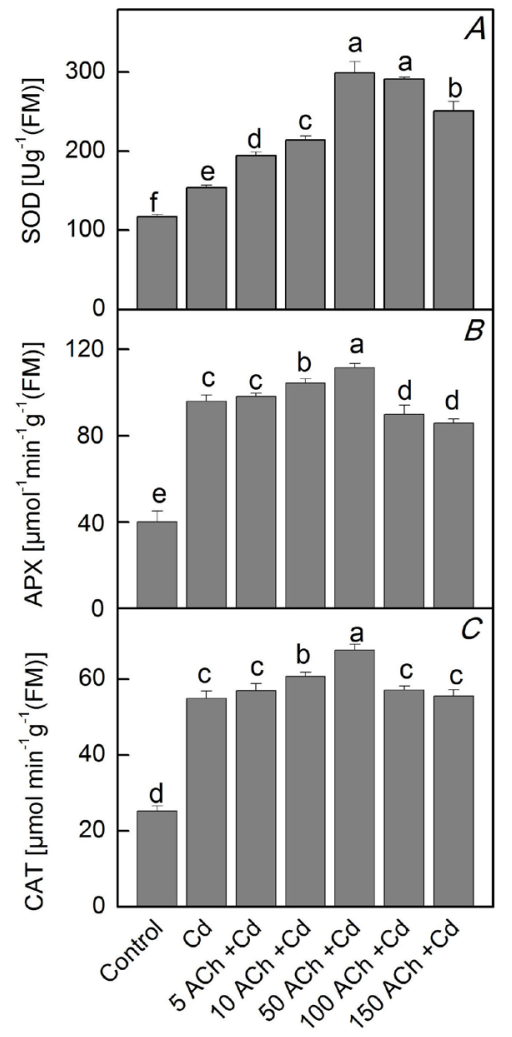

Fig. 6. Effects of exogenous acetylcholine on antioxidant enzyme activities in tobacco seedlings after $15 \mathrm{~d}$ of $\mathrm{Cd}$ stress. $(A)$ superoxide dismutase (SOD), $(B)$ ascorbate peroxidase (APX), $(C)$ catalase (CAT). Data are means of three replicates \pm SD. Bars with different letters indicate significant difference between treatments at $p \leq 0.05$ by Duncan's multiple range test. Control $1 / 2$ Hoagland nutrient solution. $\mathrm{Cd}-1 / 2$ Hoagland nutrient solution $+100 \mu \mathrm{M}$ Cd. $5,10,50,100$ or $150 \mathrm{ACh}+\mathrm{Cd}-1 / 2$ Hoagland nutrient solution +5 , $10,50,100$ or $150 \mu \mathrm{M} \mathrm{ACh}+100 \mu \mathrm{M} \mathrm{Cd}$. order to enhance the Cd tolerance of tobacco plants. Yi and Kao (2007) reported that leaf chlorosis is one of the common phenomena of Cd stress, which is well consistent with our current study where $\mathrm{Cd}$ caused leaf chlorosis or rolls (Fig. 1). Cd exposure also caused the decline in plant height, root length, and biomass accumulation, which has been attributed to hampered absorption of water and mineral nutrients (Lin et al. 2012). Furthermore, decreased photosynthetic pigment content directly affects photosynthesis and finally leads to growth inhibition. Thus, it is possible that $\mathrm{Cd}$ blocked $\mathrm{Chl}$ synthesis and further decreased $P_{\mathrm{N}}$, thereby reducing plant biomass. However, exogenously applied ACh to plants treated with $\mathrm{Cd}$ alleviated growth inhibition, which might be attributed to its ability to mediate cell elongation and division by upregulating of endotransglycosylases/hydrolases (XTHs) (Yun et al. 2010).

Photosynthetic attributes are considered as sensitive indicators of abiotic stress, which can be negatively affected by heavy metal toxicity. Reduction in Chl content and gas-exchange parameters was consistent with the finding of Kaya et al. (2020), who revealed that Cd-induced a decrease of those indexes in wheat plants exposed to Cd stress. Parmar et al. (2013) reported that reduced Chl content in Cd-stressed plants is due to inhibited synthesis of Chl precursor (aminolevulinic acid), which is linked to the reduction of protochlorophyllide to chlorophyllide. However, application of ACh $(50 \mu \mathrm{M})$ effectively promoted Chl synthesis and improved photosynthetic parameters $\left(P_{\mathrm{N}}, g_{\mathrm{s}}, C_{\mathrm{i}}\right.$, and $E$ ) (Fig. 2). This can be attributed to the fact that $\mathrm{ACh}$ promoted the synthesis of Chl-related precursors, reduced $\mathrm{Chl}$ degradation, and thus enhanced photosynthesis (Bajguz 2011). Furthermore, increased photosynthesis in ACh-treated plants may be attributed to increased $\mathrm{CO}_{2}$ assimilation and stomatal conductance (Chen et al. 2011). Chl fluorescence analysis is one of the most useful procedures for obtaining the functional status of PSII (Baryla et al. 2001). Noctor et al. (2004) 


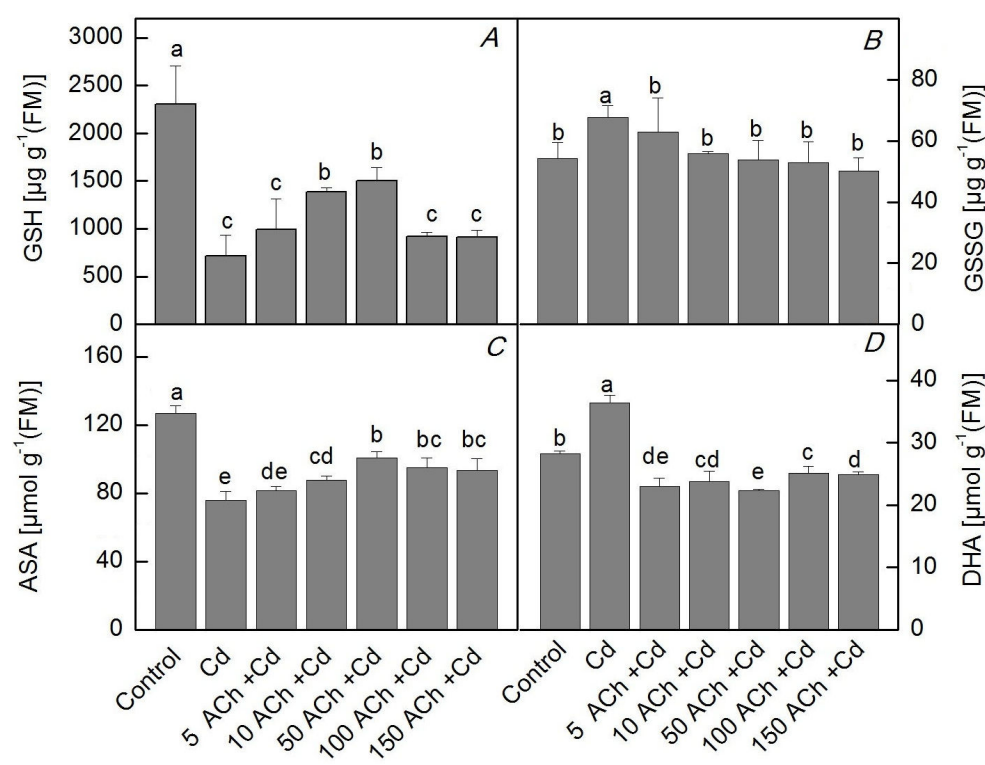

Fig. 7. Effects of exogenous acetylcholine on nonenzymatic antioxidants in tobacco seedlings after $15 \mathrm{~d}$ of $\mathrm{Cd}$ stress. (A) glutathione (GSH), $(B)$ glutathione disulfide (GSSG), (C) ascorbate (AsA), (D) dehydroascorbate (DHA). Data are means of three replicates \pm SD. Bars with different letters indicate significant difference between treatments at $p \leq 0.05$ by Duncan's multiple range test. Control $-1 / 2$ Hoagland nutrient solution. $\mathrm{Cd}$ $-1 / 2$ Hoagland nutrient solution $+100 \mu \mathrm{M} \mathrm{Cd}$. $5,10,50,100$ or $150 \mathrm{ACh}+\mathrm{Cd}-1 / 2$ Hoagland nutrient solution $+5,10,50,100$ or $150 \mu \mathrm{M} \mathrm{ACh}+$ $100 \mu \mathrm{M} \mathrm{Cd}$.
Table 1. Effects of exogenous acetylcholine (Ach) on the content of $\mathrm{Cd}$ in root and leaf tissues after $15 \mathrm{~d}$ of Cd stress. Data are the means $\pm \mathrm{SD}, n=3$. Means with the same lowercase letters are not significantly different at $p<0.05$ by Duncan's multiple range test. Control $-1 / 2$ Hoagland nutrient solution. $\mathrm{Cd}-1 / 2$ Hoagland nutrient solution $+100 \mu \mathrm{M} \mathrm{Cd} .5,10,50,100$ or $150 \mathrm{ACh}+\mathrm{Cd}$ $-1 / 2$ Hoagland nutrient solution $+5,10,50,100$ or $150 \mu \mathrm{M} \mathrm{ACh}$ $+100 \mu \mathrm{M}$ Cd. nd - not detected.

\begin{tabular}{llr}
\hline Treatment & \multicolumn{2}{l}{ Cd content $\left[\mu \mathrm{g} \mathrm{g}^{-1}(\mathrm{DM})\right]$} \\
& Leaf & \multicolumn{1}{l}{ Root } \\
\hline Control & nd & nd \\
Cd & $56.64 \pm 3.24^{\mathrm{a}}$ & $100.76 \pm 6.60^{\mathrm{a}}$ \\
$5 \mathrm{ACh}+\mathrm{Cd}$ & $40.48 \pm 4.43^{\mathrm{b}}$ & $92.86 \pm 3.36^{\mathrm{b}}$ \\
$10 \mathrm{ACh}+\mathrm{Cd}$ & $36.32 \pm 3.37^{\mathrm{bc}}$ & $81.32 \pm 2.52^{\mathrm{c}}$ \\
$50 \mathrm{ACh}+\mathrm{Cd}$ & $30.07 \pm 5.86^{\mathrm{c}}$ & $61.27 \pm 0.95^{\mathrm{e}}$ \\
$100 \mathrm{ACh}+\mathrm{Cd}$ & $35.56 \pm 4.63^{\mathrm{bc}}$ & $67.49 \pm 1.70^{\mathrm{d}}$ \\
$150 \mathrm{ACh}+\mathrm{Cd}$ & $38.34 \pm 1.67^{\mathrm{b}}$ & $72.49 \pm 3.48^{\mathrm{d}}$ \\
\hline
\end{tabular}

reported that decreased photosynthesis is due to reduced photosynthetic electron transport caused by $\mathrm{Cd}$ stress, which eventually resulted in an excessive energy generation and triggered photoinhibition. Interestingly, after exposure to $\mathrm{Cd}$ stress $\mathrm{F}_{\mathrm{v}} / \mathrm{F}_{\mathrm{m}}, \mathrm{Y}_{(\mathrm{II})}$, and $\mathrm{q}_{\mathrm{p}}$ remarkably decreased (Fig. 3). The reductions in those indexes might be caused by the restriction of light energy absorption and electron transport in PSI during Cd stress. Those results are supported by previous research of Vyas et al. (2007), who suggested that excessive ROS are the key cause of photosynthetic inhibition. Additionally, reduced $\mathrm{F}_{\mathrm{v}} / \mathrm{F}_{\mathrm{m}}$ and $\mathrm{q}_{\mathrm{P}}$ were linked to increased NPQ in Cd-stressed tobacco seedlings, indicating that the destructive energy dissipation was caused by $\mathrm{Cd}$ stress. Based on these observations, it is proposed that $\mathrm{ACh}$ can alleviate $\mathrm{Cd}$-induced photosynthesis inhibition by regulating photosynthetic capacity and improving PSII activity.

The stomata occupy a central position in regulating the complex signal transduction pathways, such as maintenance of water vapor loss in leaves (Xu and Zhou 2008). When plants were subjected to $\mathrm{Cd}$ stress, closing stomata to reduce water evaporation is a crucial mechanism of plant tolerance, which ultimately leads to a significant decrease in $g_{\mathrm{s}}$ (Bindhu and Bera 2001). It is noted that stomatal aperture and stomatal density decreased under $\mathrm{Cd}$ alone stress, whereas ACh application reversed this phenomenon (Fig. 4). The reason might be that $\mathrm{Ca}^{2+} / \mathrm{CaM}$ can act as a second messenger in ACh-induced stomatal opening and closing (Wang et al. 1999). Furthermore, ACh can mediate nicotinic and muscarinic receptors involved in this process (Wang et al. 1998, Wang et al. 2000). Therefore, this is due to the binding of ACh to its muscarinic ACh receptor, which triggers the changes of $\mathrm{Ca}^{2+}$ in guard cells. Afterwards, the influx of $\mathrm{Ca}^{2+}$ binds to $\mathrm{CaM}$, which induces downstream pathway and ultimately leads to stomatal opening (Wang et al. 2003). Thus, application of ACh might improve the development of stomata, thereby altering $g_{\mathrm{s}}$ response to $\mathrm{Cd}$ and consequently alleviation of stomatal limitation of photosynthesis.

$\mathrm{O}_{2}{ }^{-}$and $\mathrm{H}_{2} \mathrm{O}_{2}$ are the major ROS induced by $\mathrm{Cd}$ stress which can cause oxidative damage, directly inhibit or modify some proteins and ultimately lead to cell death (Pospíšil 2014). In the current study, exogenously applied $\mathrm{ACh}$ reduced the ROS accumulation, indicating that $\mathrm{ACh}$ application promoted the tolerance of plants to $\mathrm{Cd}$ stress by reducing ROS production. MDA and proline values are generally considered as vital indicators of membrane permeability or the loss of membrane integrity under metal stress (Fan et al. 2015). Previous study has confirmed that enhanced contents of $\mathrm{H}_{2} \mathrm{O}_{2}$ can lead to lipid peroxidation, which causes damage of the cell membrane (Sairam and Srivastava 2002). Interestingly, significant increases in MDA and proline were observed in Cd alone-treated plants (Fig. 5), which indicated that the free radical formation was stimulated by $\mathrm{Cd}$ toxicity, generating serious lipid peroxidation and leading to plasma membrane injury. Similar results were reported in Triticum aestivum L. 
(Moussa and El-Gamal 2010) and Brassica juncea (Kaur et al. 2019) plants. However, application of ACh under $\mathrm{Cd}$ stress resulted in decrease of MDA content. Rahman et al. (2017) suggested that exogenous substances reduced free radical production by maintaining normal water and proline contents in cell. Hence, we hypothesized that ACh might maintain cell membrane stability by participating in the osmotic adjustment pathway responded to $\mathrm{Cd}$ stress.

Besides, the activity of antioxidant enzymes (SOD, CAT, and APX) plays an important role in Cd-induced oxidative stress. Hasan et al. (2015), who reported that $\mathrm{Cd}$ phytotoxicity could be mitigated by enhancing antioxidant potential after application of exogenous substance in Solanum lycopersicum L. Notably, Cd stress promoted the activities of SOD, CAT, and APX, whereas application of $50 \mu \mathrm{M}$ ACh further increased these indexes in leaves during $\mathrm{Cd}$ exposure (Fig. 6), which indicated that exogenously applied ACh could activate the activity of antioxidant enzymes, thus alleviating $\mathrm{Cd}$ toxicity. GSH and AsA are major nonenzymatic antioxidants in the AsA-GSH cycle and play important roles in ROS scavenging (Schützendübel and Polle 2002). GSH acts as a redox buffer involved in antioxidant system, which is associated with the sequestration of $\mathrm{Cd}$ ions in the vacuoles. Interestingly, it was noticed that $\mathrm{H}_{2} \mathrm{O}_{2}$ and $\mathrm{O}_{2}{ }^{--}$ contents significantly decreased at lower concentration $(5 \mu \mathrm{M})$ of $\mathrm{ACh}$ in treated plants, which indicated that the low concentration of ACh may promote the content of GSH and AsA, and consequently enhance ROS scavenging. These observations suggested that $\mathrm{ACh}$-induced alleviation of oxidative stress is related to the enhancement of antioxidant enzymes activities and improvement of redox homeostasis in tobacco plants.

More $\mathrm{Cd}$ was accumulated in roots than that in leaves, which was associated with decreased transpiration rate and the decrease of $\mathrm{Cd}$ flux from roots to leaves due to the transport of $\mathrm{Cd}$ by the apoplastic pathway (Sterckeman et al. 2011). In our study, the higher concentration of Cd in roots than that in leaves may be related to the above reasons. The similar phenomenon was also found in tomato plants subjected to Cd exposure (Li et al. 2016). Previous study has shown that the reduction of $\mathrm{Cd}$ detoxification is also linked to cell wall binding, chelation with phytochelatins, and vacuolar sequestration (Lai 2015). In the current study, pretreatment with ACh obviously decreased the uptake of $\mathrm{Cd}$ in root and leaf tissues, compared to $\mathrm{Cd}$ stress alone (Table 1). These phenomena may be attributed to ACh, which can fix more $\mathrm{Cd}$ to the cell wall, sequester $\mathrm{Cd}$ in the vacuoles, then convert it into co-precipitation in the cytosol, thereby inhibiting the transport of $\mathrm{Cd}$ from the roots to shoots (Zhou et al. 2017).

Conclusions: It can be concluded that exogenous application of acetylcholine effectively improved the photosynthetic capacity and photochemistry of PSII as well as stomatal development. Moreover, acetylcholine induced ROS elimination as evidenced by upregulated antioxidant enzyme activity and maintenance of redox homeostasis. Thus, acetylcholine may act as a potential modulator of plant growth and play a critical role in plants tolerance to $\mathrm{Cd}$. Further studies are needed to provide more molecular and genetic evidence to reveal the mechanism of acetylcholine involving $\mathrm{Cd}$ tolerance in plants.

\section{References}

Ahmad P., Ahanger M.A., Alyemeni M.N. et al.: Exogenous application of nitric oxide modulates osmolyte metabolism, antioxidants, enzymes of ascorbate-glutathione cycle and promotes growth under cadmium stress in tomato. Protoplasma 255: 79-93, 2018.

Antoniou C., Chatzimichail G., Xenofontos R. et al.: Melatonin systemically ameliorates drought stress-induced damage in Medicago sativa plants by modulating nitro-oxidative homeostasis and proline metabolism. - J. Pineal Res. 62: e12401, 2017.

Apel K., Hirt H.: Reactive oxygen species: Metabolism, oxidative stress, and signal transduction. - Annu. Rev. Plant Biol. 55: 373-399, 2004.

Asada K.: Ascorbate peroxidase - a hydrogen peroxidescavenging enzyme in plants. - Plant Physiol. 85: 235-241, 1992.

Asada K.: Production and scavenging of reactive oxygen species in chloroplasts and their functions. - Plant Physiol. 141: 391-396, 2006.

Bajguz A.: Suppression of Chlorella vulgaris growth by cadmium, lead and copper stress and its restoration by endogenous brassinolide. - Arch. Environ. Contam. Tox. 60: 406-416, 2011.

Baryla A., Carrier P., Franck F. et al.: Leaf chlorosis in oilseed rape plants (Brassica napus) grown on cadmium-polluted soil: causes and consequences for photosynthesis and growth. - Planta 212: 696-709, 2001.

Bates L.S., Waldren R.P., Teare I.D.: Rapid determination of free proline for water-stress studies. - Plant Soil 39: 205-207, 1973.

Bindhu S.J., Bera A.K.: Impact of cadmium toxicity on leaf area, stomatal frequency, stomatal index and pigment content in mungbean seedlings. - J. Environ. Biol. 22: 307-309, 2001.

Braga I., Pissolato M.D., Souza G.M.: Mitigating effects of acetylcholine supply on soybean seed germination under osmotic stress. - Braz. J. Bot. 40: 617-624, 2017.

Cakmak I., Marschner H.: Magnesium deficiency and high light intensity enhance activities of superoxide dismutase, ascorbate peroxidase, and glutathione reductase in bean leaves. - Plant Physiol. 98: 1222-1227, 1992.

Chen X., Wang J., Shi Y. et al.: Effects of cadmium on growth and photosynthetic activities in pakchoi and mustard. - Bot. Stud. 52: 41-46, 2011.

Cho U.H., Seo N.H.: Oxidative stress in Arabidopsis thaliana exposed to cadmium is due to hydrogen peroxide accumulation. - Plant Sci. 168: 113-120, 2005.

Christensen H.T., Zhang Z., Wei Y. et al: $\mathrm{H}_{2} \mathrm{O}_{2}$ accumulation in papillae and hypersensitive response during the barleypowdery mildew interaction. - Plant J. 11: 1187-1194, 1997.

Clemens S.: Toxic metal accumulation, responses to exposure and mechanisms of tolerance in plants. - Biochimie 88: 1707$1719,2006$.

Fan J., Hu Z., Xie Y. et al.: Alleviation of cold damage to photosystem II and metabolisms by melatonin in Bermuda grass. - Front. Plant Sci. 6: 925, 2015.

Genty B., Briantais J.M., Baker N.B.: The relationship between 
the quantum yield of photosynthetic electron transport and quenching of chlorophyll fluorescence. - BBA-Gen. Subjects 990: 87-92, 1989.

Giannopolitis C.N., Ries S.K.: Superoxide dismutases. 1. Occurrence in higher-plants. - Plant Physiol. 59: 309-314, 1977.

Gill S.S., Tuteja N.: Reactive oxygen species and antioxidant machinery in abiotic stress tolerance in crop plants. - Plant Physiol. Bioch. 48: 909-930, 2010.

Hasan M.K., Ahammed G.J., Yin L. et al.: Melatonin mitigates cadmium phytotoxicity through modulation of phytochelatins biosynthesis, vacuolar sequestration, and antioxidant potential in Solanum lycopersicum L. - Front. Plant Sci. 6: 601, 2015.

Horiuchi Y., Kimura R., Kato N. et al.: Evolutional study on acetylcholine expression. - Life Sci. 72: 1745-1756, 2003.

Kampfenkel K., Van Montaqu M., Inzé D.: Extraction and determination of ascorbate and dehydroascorbate from plant tissue. - Anal. Biochem. 225: 165-167, 1995.

Kapoor D., Singh M.P., Kaur S. et al.: Modulation of the functional components of growth, photosynthesis, and anti-oxidant stress markers in cadmium exposed Brassica juncea L. - Plants-Basel 8: 260, 2019.

Kaur P., Bali S., Sharma A. et al.: Cd induced generation of free radical species in Brassica juncea is regulated by supplementation of earthworms in the drilosphere. - Sci. Total Environ. 655: 663-675, 2019.

Kawashima K., Misawa H., Moriwaki Y. et al.: Ubiquitous expression of acetylcholine and its biological functions in life forms without nervous systems. - Life Sci. 80: 2206-2209, 2007.

Kaya C., Ashraf M., Alyemeni M.N., Ahmad P.: Responses of nitric oxide and hydrogen sulfide in regulating oxidative defence system in wheat plants grown under cadmium stress. - Physiol. Plantarum 168: 345-360, 2020.

Kim J.M., Woo D.H., Kim S.H. et al.: Arabidopsis MKKK20 is involved in osmotic stress response via regulation of MPK6 activity. - Plant Cell Rep. 31: 217-224, 2012.

Lai H.Y.: Subcellular distribution and chemical forms of cadmium in Impatiens walleriana in relation to its phytoextraction potential. - Chemosphere 138: 370-376, 2015.

Li M.Q., Hasan M.K., Li C.X. et al.: Melatonin mediates selenium-induced tolerance to cadmium stress in tomato plants. - J. Pineal Res. 61: 291-302, 2016.

Li Q., Wang G., Wang Y. et al.: Foliar application of salicylic acid alleviate the cadmium toxicity by modulation the reactive oxygen species in potato. - Ecotox. Environ. Safe. 172: 317-325, 2019.

Lin L., Zhou W., Dai H. et al.: Selenium reduces cadmium uptake and mitigates cadmium toxicity in rice. - J. Hazard. Mater. 235-236: 343-351, 2012.

Masato O.: An improved method for determination of L-ascorbic acid and L-dehydroascorbic acid in blood plasma. - Clin. Chim. Acta 103: 259-268, 1980.

Momonoki Y.S., Tokuhiro M.: The influence of heat stress on acetylcholine content and its hydrolyzing activity in Macroptilium atropurpureum cv. Siratro. - Jpn. J. Crop Sci. 61: 112-118, 1992.

Moussa H.R., El-Gamal S.M.: Role of salicylic acid in regulation of cadmium toxicity in wheat (Triticum aestivum L.). J. Plant Nutr. 33: 1460-1471, 2010.

Nakano Y., Asada K.: Hydrogen peroxide is scavenged by ascorbate-specific peroxidase in spinach chloroplasts. - Plant Cell Physiol. 22: 867-880, 1981.

Noctor G., Dutilleul C., De Paepe R., Foyer C.H.: Use of mitochondrial electron transport mutants to evaluate the effects of redox state on photosynthesis, stress tolerance and the integration of carbon/nitrogen metabolism. - J. Exp. Bot. 55: 49-57, 2004.

Parmar P., Kumari N., Sharma V.: Structural and functional alterations in photosynthetic apparatus of plants under cadmium stress. - Bot. Stud. 54: 45, 2013.

Patterson B.D., MacRae E.A., Ferguson I.B.: Estimation of hydrogen peroxide in plant extracts using titanium(IV). Anal. Biochem. 139: 487-492, 1984.

Pospíšil P.: The role of metals in production and scavenging of reactive oxygen species in photosystem II. - Plant Cell Physiol. 55: 1224-1232, 2014.

Qin C., Su Y.Y., Li B.S. et al.: Acetylcholine mechanism of action to enhance tolerance to salt stress in Nicotiana benthamiana. Photosynthetica 57: 590-598, 2019.

Rahman M.F., Ghosal A., Alam M.F., Kabir A.H.: Remediation of cadmium toxicity in field peas (Pisum sativum L.) through exogenous silicon. - Ecotox. Environ. Safe. 135: 165-172, 2017.

Sagane Y., Nakagawa T., Yamamoto K. et al.: Molecular characterization of maize acetylcholinesterase: a novel enzyme family in the plant kingdom. - Plant Physiol. 138: 1359-1371, 2005.

Sairam P.K., Srivastava G.C.: Changes in antioxidant activity in sub-cellular fractions of tolerant and susceptible wheat genotypes in response to long term salt stress. - Plant Sci. 162: 897-904, 2002.

Schopfer P., Plachy C., Frahry G.: Release of reactive oxygen intermediates (superoxide radicals, hydrogen peroxide, and hydroxyl radicals) and peroxidase in germinating radish seeds controlled by light, gibberellin, and abscisic acid. - Plant Physiol. 125: 1591-1602, 2001.

Schützendübel A., Polle A.: Plant responses to abiotic stresses: heavy metal-induced oxidative stress and protection by mycorrhization. - J. Exp. Bot. 53: 1351-1365, 2002.

Sharma A., Kumar V., Shahzad B. et al.: Photosynthetic response of plants under different abiotic stresses: a review. - J. Plant Growth Regul. 38: 1-23, 2019.

Smith I.K.: Stimulation of glutathione synthesis in photorespiring plants by catalase inhibitors. - Plant Physiol. 79: 1044-1047, 1985.

Snider J.L., Choinski J.S., Wise R.R.: Juvenile Rhus glabra leaves have higher temperatures and lower gas exchange rates than mature leaves when compared in the field during periods of high irradiance. - J. Plant Physiol. 166: 686-696, 2009.

Sterckeman T., Redjala T., Morel J.L.: Influence of exposure solution composition and of plant cadmium content on root cadmium short-term uptake. - Environ. Exp. Bot. 74: 131139, 2011.

Sugiyama K., Tezuka T.: Acetylcholine promotes the emergence and elongation of lateral roots of Raphanus sativus. - Plant Signal. Behav. 6: 1545-1553, 2011.

Tambussi E.A., Casadesus J., Munné-Bosch S., Araus J.L.: Photoprotection in water-stressed plants of durum wheat (Triticum turgidum var. durum): changes in chlorophyll fluorescence, spectral signature and photosynthetic pigments. Funct. Plant Biol. 29: 35-44, 2002.

Tonutti P., Bonghi C., Ruperti B. et al.: Ethylene evolution and 1-aminocyclopropane-1-carboxylate oxidase gene expression during early development and ripening of peach fruit. - J. Am. Soc. Hortic. Sci. 122: 642-647, 1997.

Tretyn A., Kendrick R.E.: Acetylcholine in plants: presence, metabolism and mechanism of action. - Bot. Rev. 57: 33-73, 1991.

Vyas D., Kumar S., Ahuja P.S.: Tea (Camellia sinensis) clones with shorter periods of winter dormancy exhibit lower accumulation of reactive oxygen species. - Tree Physiol. 27: 
1253-1259, 2007.

Wang H.B., Wang X.C., Lou C.H.: Relationship between acetylcholine and stomatal movement in Vicia faba. - Acta Bot. Sin. 41: 171-175, 1999.

Wang H.B., Wang X.C., Zhang S.Q. et al.: Nicotinic acetylcholine receptor is involved in acetylcholine regulating stomatal movement. - Sci. China Ser. C Life Sci. 41: 650-656, 1998.

Wang H.B., Wang X.C., Zhang S.Q., Lou C.H.: Muscarinic acetylcholine receptor is involved in acetylcholine regulating stomatal movement. - Chinese Sci. Bull. 45: 250-252, 2000.

Wang H.B., Zhang S.Q., Wang X.C., Lou C.H.: Involvement of $\mathrm{Ca}^{2+} / \mathrm{CaM}$ in the signal transduction of acetylcholine regulating stomatal movement. - Chinese Sci. Bull. 48: 351$354,2003$.

Wintermans J.F.G.M., De Mots A.: Spectrophotometric characteristics of chlorophylls $a$ and $b$ and their phenophytins in ethanol. - BBA-Biophysics 109: 448-453, 1965.
Wu F.B., Dong J., Qian Q.Q., Zhang G.P.: Subcellular distribution and chemical form of $\mathrm{Cd}$ and $\mathrm{Cd}-\mathrm{Zn}$ interaction in different barley genotypes. - Chemosphere 60: 1437-1446, 2005.

Xu Z., Zhou G.: Responses of leaf stomatal density to water status and its relationship with photosynthesis in a grass. J. Exp. Bot. 59: 3317-3325, 2008.

Yi T.H., Kao C.H.: Heat shock-mediated $\mathrm{H}_{2} \mathrm{O}_{2}$ accumulation and protection against $\mathrm{Cd}$ toxicity in rice seedlings. - Plant Soil 300: 137-147, 2007.

Yun H.S., Kwon C., Kang B.G. et al.: A xyloglucan endotransglycosylase/hydrolase $1, \mathrm{VrXTH} 1$, is associated with cell elongation in mungbean hypocotyls. - Physiol. Plantarum 125: 106-113, 2010.

Zhou J.T., Wan H.X., He J.L. et al.: Integration of cadmium accumulation, subcellular distribution, and physiological responses to understand cadmium tolerance in apple rootstocks. - Front. Plant Sci. 8: 966, 2017.

(C) The authors. This is an open access article distributed under the terms of the Creative Commons BY-NC-ND Licence. 